\title{
One day more
}

\section{While I was suffering from asevere case of the fut his \\ While winter, I was desperate for as sutable remedity.} Then I was reminded of Victor Hugo's words: "Those who live are those who fight."

As the year 2012 draws to a close, it is worth turning our attention to a remarkable flu fighter, Dr. Ron Fouchier. He is a virologist at the Erasmus Medical Center in Rotterdam, the Netherlands, and was listed by Nature as one of ten people who mattered this year.

If you were already familiar with his work on creating a strain of the $\mathrm{H}_{5} \mathrm{Nl}$ avian flu virus capable of spreading between mammals, you should be familiar with the dispute on 'dual-use' research that can be both beneficial to the public when used in good will and threatening to society if it is misused.

Dr. Fouchier had already obtained his results in 2011 and submitted his paper to Science in that year, but the US National Science Advisory Board for Biosecurity (NSABB) held up the publication process because of the study's potential utility for bioterrorism if the full paper were to be printed, and the NSABB recommended in December 2011 that the experimental details be redacted. Nevertheless, Dr. Fouchier persistently demanded comprehensive recognition of his work, and in March of the following year, the NSABB issued a revised opinion allowing full paper publication.

However, Dr. Fouchier's fight was not done. Even though a similar 
controversial avian flu paper by Dr. Yoshihiro Kawaoka was successfully published in Nature this past May, Dr. Fouchier's work for Science was then obstructed by European Union (EU) legislation on export controls. This meant that while the NSABB decided Dr. Kawaoka's work no longer fell under US and Japanese export controls, the Dutch government asserted that Dr. Fouchier's paper should be controlled by Dutch and EU export controls law 'EC 428/2009.' Because he had expressed the intention of defying the Dutch government to submit his paper to Science without seeking an export permit, he was threatened with punishment of up to six years' imprisonment.

Although in the end Dr. Fouchier was able to obtain a permit from the Dutch government and his paper was released in this June's issue of Science, he is still embroiled in legal proceedings to contest the rigorous EU export control law itself.

Dr. Fouchier has stated, "If there is anything I can do to prevent future generations of infectious disease specialists being censored against their will by government, I will do it." We, as thoughtful scientific researchers, can stand by him, because protecting the right to freely publish our good work is worth the fight.

\section{Tae-II Kim}

Editor-in-Chief

Department of Periodontology, Seoul National University School of Dentistry, 101 Daehak-ro,

Jongno-gu, Seoul 110-749, Korea

E-mail: periopf@snu.ac.kr, Tel: +82-2-2072-2642, Fax: +82-2-744-1349 